\title{
Biological Characteristies of a Cold-adapted Influenza A Virus Mutation Residing on a Polymerase Gene
}

\author{
By

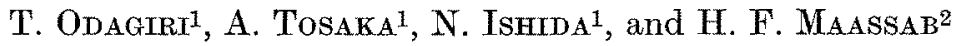 \\ 1 Department of Bacteriology, Tohoku University, School of Medicine, Sendai, Japan \\ 2 Department of Epidemiology, School of Public Health, The University of Michigan \\ Ann Arbor, Michigan, U.S.A.
}

With 3 Figures

Accepted June 7, 1985

\begin{abstract}
Summary
The biological function of a cold-adapted(ca) mutation residing on the PB2 gene of an influenza A/Ann Arbor/6/60 (A/AA/6/60) ca variant virus in the viral replication cycle at $25^{\circ} \mathrm{C}$ was studied. The viral polypeptide synthesis of $\mathrm{A} / \mathrm{AA} / 6 / 60$ ca variant at $25^{\circ} \mathrm{C}$ was evident approximately 6 hours earlier than the wild type (wt) virus and yielded twice as many products. The quantitative analysis of viral complementary RNA (cRNA), synthesized in the presence of cycloheximide, revealed that $A / A A / 6 / 60$ ca variant and a single gene reassortant that contains only the PB 2 gene of the ca variant with remaining genes of the wt virus produced equal amount of cRNA at $25^{\circ}$ and $33^{\circ} \mathrm{C}$, which was an amount approximately four fold greater than the wt virus' $\mathrm{eRNA}$ synthesized at $25^{\circ} \mathrm{C}$. These results strongly suggest that the ca mutation residing on the PB2 gene of A/AA/6/60 ca variant affects the messenger RNA synthesis at $25^{\circ} \mathrm{C}$ in the primary transcription.
\end{abstract}

\section{Introduction}

A cold-adapted variant of $\mathrm{A} / \mathrm{Ann}$ Arbor/6/60 (A/AA/6/60) influenza virus was developed by serial passages in primary chick kidney (PCK) cells by gradually lowering the incubation temperature to $25^{\circ} \mathrm{C}$ which restricted the growth of the wt strain $(17,18)$. The A/AA/6/60 variant strain has been found to possess two inheritable plaquing phenotypes. One is the coldadapted (ca) property which is the ability to grow to high titer at $25^{\circ} \mathrm{C}$. The other is the temperature-sensitive (ts) property with a shutoff tem- 
perature of $37^{\circ}$ or $38^{\circ} \mathrm{C}(16,17,18,27)$. Reassortants that possessed the six nonglycoprotein genes of $\mathrm{A} / \mathrm{AA} / 6 / 60$ variant and the two glycoprotein genes of a wt virus, were attenuated to both animals and humans $(18,21$, 27), possessed good immunogenic qualities $(5,29,32)$, and they were genetically stable (8). Thus, the $\mathrm{A} / \mathrm{AA} / 6 / 60$ ca variant virus is currently the most useful master strain for developing live influenza vaccine lines.

Identification of the ca $\mathrm{A} / \mathrm{AA} / 6 / 60$ variant genes responsible for the ca and ts properties have been hampered due to two commonly encountered difficulties; 1 . the lack of single-gene reassortants bearing the ca or ts properties and 2. the lack of a diversity in the gene constellations of reassortant viruses. Assignment of gene constellations using a large number of ea reassortant clones, formed by mating the $\mathrm{A} / \mathrm{AA} / 6 / 60$ ca variant and wt viruses, suggests that the ts property of the ca reassortant is not determined by a single gene of the $\mathrm{A} / \mathrm{AA} / 6 / 60 \mathrm{ca}$ variant $(6,7,23)$.

The function of the ca mutation in the viral replication cycle and the gene(s) involved in ca property of $\mathrm{A} / \mathrm{AA} / 6 / 60$ ca variant have yet to be unequivocally identified. Previously, we developed ca and non ts phenotypic reassortant clones using canine kidney (MDCK) cells at a non-selective temperature of $33^{\circ} \mathrm{C}(23)$. Some of the single-gene reassortants that possessed only RNA 2 coding for the PB 2 gene or RNA 5 coding for the neuraminidase (NA) gene of $\mathrm{A} / \mathrm{AA} / 6 / 60$ ca variant, were involved in the ca and non ts phenotypes. There reassortants allowed us to determine the function of the ca mutation in viral attenuation in mice (24) as well as the biological mechanism that operates to lower the viral replication range to $25^{\circ} \mathrm{C}$.

The present study describes the effects of a ca mutation residing on the PB2 gene of $\mathrm{A} / \mathrm{AA} / 6 / 60$ variant strain. Using the PB2 single-gene ca reassortant virus, we found that the PB2-ca mutation affects both polymerase activity and messenger RNA synthesis in primary transcription at $25^{\circ} \mathrm{C}$.

\section{Materials and Methods}

Viruses and Tissue Cultures

Influenza A viruses used in the present study were a 8 PI-A/Ann Arbor/6/60 (H 2N2) cold-adapted (ca) variant (17), an A/Ann Arbor/6/60 (H 2N 2) wild type strain, an $\mathrm{A} /$ Alaska/6/77 (H $3 \mathrm{~N} 2$ ) and the ca reassortant clones of the A/Ann Arbor/6/60 ca variant and $\mathrm{A} /$ Alaska/6/77 virus (23).

Madin-Darby canine kidney (MDCK) cells (Flow Laboratory, Rockville, Md.) were used between the 60 th and 75 th passage levels. The cell cultures were maintained in an Eagle's MEM containing 10 per cent heat-inactivated fetal calf serum and were used for subsequent viral growth curve and biochemical analysis.

\section{Viral Growth Curve Analysis}

Confluent MDCK monolayers in $25 \mathrm{~cm}^{2}$ plastic bottles were infected with the viruses at a multiplicity of infection (MOI) of 1.0 plaque-forming unit (PFU) per cell in double-strength Eagle's basal medium ( $2 \mathrm{X}$ Eagle's) containing $5 \mu \mathrm{g} / \mathrm{ml}$ of TPCK 
trypsin. After 1 hour adsorption at room temperature, cultures were washed twice with $5 \mathrm{ml}$ of Hank's balanced salt solution (HBSS). The washed cultures were then incubated with $1 \mathrm{ml}$ of diluted chicken A/Ann Arbor/6/60 ca variant antiserum for A/Ann Arbor/6/60 ca variant and for the wild type virus; or with $1 \mathrm{ml}$ of diluted A/ Bangkok/1/79(H3)-Equine/Prague/1/56(N 7$)$ antiserum for the ca reassortant viruses (hemagglutination-inhibition titer of $1: 50$ ) for 30 minutes at room temperature to neutralize any unpenetrated viruses. The antisera were then removed by two washings and the cultures were incubated at $25^{\circ}$ or $33^{\circ} \mathrm{C}$ with $2 \mathrm{ml}$ of $2 \mathrm{X}$ Eagle's containing $5 \mu \mathrm{g} / \mathrm{ml}$ of TPCK trypsin. The virus released into the supernatant fluid was harvested at various time intervals. The cultures were washed once with $5 \mathrm{ml}$ of prewarmed HBSS, followed by a supplement with $2 \mathrm{ml}$ of prewarmed $2 \mathrm{X}$ Eagle's for further incubation. The virus titer in the supernatant fluid was evaluated by plaque assay on MDCK monolayer cells at $33^{\circ}$, as previously deseribed (23).

\section{Virion Associated RNA-dependent RNA Polymerase Assay}

In vitro virion $\mathrm{RNA}$ polymerase activity was analyzed by the method described by Plotch and KRUg (25). Approximately $20 \mu \mathrm{g}$ of purified virion protein was suspended in a small volume of STE (100 mM NaCl, $10 \mathrm{~mm}$ Tris- $\mathrm{HCl} \mathrm{pH} 7.5,1 \mathrm{~mm}$ EDTA) and disrupted with $10 \mathrm{mir}$ of $\mathrm{NaCl}$ and 0.2 per cent of Triton $\mathrm{N} 101$. The disrupted virion was added to the reaction mixture of a final volume of $50 \mu \mathrm{l}$, containing 50 mu Tris- $\mathrm{HCl}$ ( $\mathrm{pH} 7.8$ ), $100 \mathrm{~mm} \mathrm{KCl,} 1 \mathrm{~mm}$ dithiothreitol, $5 \mathrm{~mm} \mathrm{MgCl} 2,1 \mathrm{~mm}$ three ribonucleoside triphosphates, $2 \mu \mathrm{Ci}{ }^{3} \mathrm{H}$-UTP (specific activity $38.5 \mathrm{Ci} / \mathrm{mmol}$ ) and $0.4 \mathrm{~mm} A \mathrm{ApG}$ as a primer. The duplicate samples were then incubated at either $25^{\circ}$ or $33^{\circ} \mathrm{C}$. The reactions were terminated at various time intervals by the addition of $1 \mathrm{ml}$ of cold 10 per cent trochloroacetic acid (TCA) containing $0.1 \mathrm{M}$ sodium pyrophosphate. After 30 minutes at $0^{\circ} \mathrm{C}$, the precipitated RNA was collected on a Whatman GF/C filter, and then washed; first with $20 \mathrm{ml}$ of cold 5 per cent TCA containing $0.1 \mathrm{M}$ sodium pyrophosphate and then with $20 \mathrm{ml}$ of cold ethanol. Radioactivity was determined in a scintillation spectrometer after adding $5 \mathrm{ml}$ of aqueous counting scintillant (ACS II, Amersham Corp.).

\section{Preparation of Infected Cell RNA}

MDCK monolayer cultures grown in $75 \mathrm{~cm}^{2}$ plastic bottles $\left(2.2 \times 10^{7}\right.$ cells/culture $)$ were infected at an MOI of 50 PFU/cell in the presence of $100 \mu \mathrm{g} / \mathrm{ml}$ cycloheximide. After adsorption for 30 minutes at room temperature, the inocula were removed and the cultures were washed 3 times with $10 \mathrm{ml}$ of cold HBSS. The virus infected cells were incubated at $25^{\circ} \mathrm{C}$ for 5 hours or at $33^{\circ} \mathrm{C}$ for 3 hours in the growth medium as described by Sucrura et al. (28) in the presence of $100 \mu \mathrm{g} / \mathrm{ml}$ cycloheximide. Zero time corresponds to the time at which the infected cells were brought to the aforementioned temperatures.

At the indicated times, the infected cells were collected into reticulocytes standard buffer $\left(0.01 \mathrm{M} \mathrm{KCl}, 0.0015 \mathrm{Mr} \mathrm{MgCl}_{2}, 0.01 \mathrm{mr}\right.$ Tris-HCl $\mathrm{pH} \mathrm{7.4)}$, and were extracted 5 to 7 times with phenol-chloroform, as described previously (19). The ethanol precipitated RNA was desalted followed by chromatography through PD-10 column (Sephadex G-25 M) in water. The RNAs in the excluded volume were then pooled and lyophilized to dryness.

\section{Quantitative Analysis of Virus-specific RNA}

Measurements of virus specific complementary RNA (cRNA) were made by annealing with ${ }^{3} \mathrm{H}$-labeled viral RNA ( ${ }^{3} \mathrm{H}-\mathrm{v}$ RNA) extracted from purified virion. The proce. dures for RNA-RNA annealing experiments were based on the methods of GLAss et al. (9) and KRvg et al. (12). Three micrograms of ${ }^{3} \mathrm{H}-\mathrm{vRNA}$ were mixed with $20 \mu \mathrm{g}$ 
of virus-infected cellular RNA in a final volume of $100 \mu \mathrm{l}$ of $2 \times \mathrm{SSC}$ in an Eppendorf tube. After boiling at $98^{\circ} \mathrm{C}$ for 5 minutes, the mixture was immersed in a $68^{\circ} \mathrm{C}$ water bath for 4 hours and then slowly cooled for 18 hours at $25^{\circ} \mathrm{C}$. One-half of the sample was treated with $10 \mu \mathrm{g} / \mathrm{ml}$ of pancreatic RNase and 50 units $/ \mathrm{ml}$ of T1 RNase for 30 minutes at $37^{\circ} \mathrm{C}$. The other half was left untreated. The RNase resistant RNA was determined as described previously (12).

\section{Synthesis of Viral Polypeptides}

Confluent MDOK monolayers were inoculated at an MOI of $50 \mathrm{PFU} / \mathrm{cell}$ for $30 \mathrm{~min}$ utes at room temperature and then incubated in $2 \times$ Eagle's medium at $25^{\circ} \mathrm{C}$. At various times after infection, the medium was replaced with $1 \mathrm{ml}$ of prewarmed $2 \times$ Eagle's medium deficient in amino acids. After incubation for 45 minutes at $25^{\circ} \mathrm{C}$, the infected cells were treated with $150 \mathrm{~mm} \mathrm{NaCl}$ for 15 minutes before the addition of the radioactive label as described previously (15). The medium was removed and replaced with $0.2 \mathrm{ml}$ of $2 \times$ Eagle's medium deficient in amino acids and containing $50 \mu \mathrm{Ci} / \mathrm{ml}$ of ${ }^{14} \mathrm{C}-\mathrm{L}$-amino acid mixtures for exactly 20 minutes at $25^{\circ} \mathrm{C}$. The labeling medium was then rapidly removed and cells were lysed in $100 \mu l$ of lysis buffer (14). Lysates were scraped from the culture tubes, boiled at $100^{\circ} \mathrm{C}$ for 1 minutes, sonicated, and frozen at $-20^{\circ} \mathrm{C}$.

\section{Polyacrylamide Gel Electrophoresis (PAGE)}

Virus specific polypeptides in infected cells were analyzed by high-resolution discontinuous PAGE using Tris-glycine buffer with SDS (13). This procedure was described previously in detail (23).

\section{Results}

\section{Characteristics of Viral Growth at Various Temperatures}

In this study, we attempted to determine the stage(s) in the viral replication cycle which are affected by mutation of $\mathrm{A} / \mathrm{AA} / 6 / 60$ ca variant strain, resulting in equivalent virus yield at $25^{\circ}$ and $33^{\circ} \mathrm{C}$ as previously reported by MaAssab $(17,18)$. To investigate this phenomenon, infected cells were initially incubated at $33^{\circ} \mathrm{C}$ for 4 hours, followed by a temperature shift down to $25^{\circ} \mathrm{C}$ (Table 1). The infectious particles of the ca variant and $\mathrm{A} / \mathrm{AA} / 6 / 60$ wt virus were detected as early as 6 hours after the temperature was shifted down. The titers of the wt virus at each time interval

Table 1. Virus production at $25^{\circ} \mathrm{C}$ after temperature shift-down from $33^{\circ} \mathrm{C}$

\begin{tabular}{|c|c|c|c|c|c|}
\hline \multirow[b]{2}{*}{ Viruses } & \multicolumn{5}{|c|}{ Virus titer $(\log 10 \mathrm{PFU} / \mathrm{ml})$ at indicated times (hours) } \\
\hline & 6 & 12 & 18 & 24 & 30 \\
\hline $\mathrm{A} / \mathrm{AA} / 6 / 60 \mathrm{ca}$ & 3.0 & 4.0 & 5.0 & 5.2 & 5.9 \\
\hline $\mathrm{A} / \mathrm{AA} / 6 / 60 \mathrm{wt}$ & 2.5 & 3.9 & 4.3 & 5.1 & 5.2 \\
\hline
\end{tabular}

MDCK monolayers were infected with the viruses at an MOI $10 \mathrm{PFU} /$ cell and the aliquot samples were harvested at the indicated time intervals 
Table 2. Virus production at $33^{\circ} \mathrm{C}$ after temperature shift-up from $25^{\circ} \mathrm{Ca}$

\begin{tabular}{lllll}
\hline & \multicolumn{4}{l}{ Virus titer $(\log 10 \mathrm{PFU} / \mathrm{ml})$} \\
\cline { 2 - 5 } Viruses & 3 & 6 & 9 & 12 \\
\hline $\mathrm{A} / \mathrm{AA} / 6 / 60 \mathrm{ca}$ & 3.0 & 5.0 & 5.8 & 6.3 \\
$\mathrm{~A} / \mathrm{AA} / 6 / 60 \mathrm{wt}$ & N.D.b & 3.9 & 4.5 & 6.0 \\
$\mathrm{~T}_{2} 36-3-1$ & 4.1 & 5.3 & 5.7 & 6.3 \\
\hline
\end{tabular}

a Immediatly after infection, the infected cells were incubated at $25^{\circ} \mathrm{C}$ for 6 hours. The temperature was then elevated to $33^{\circ} \mathrm{C}$

b N.D.: not detected

were almost equal to those of the ca variant in spite of being incubated at $25^{\circ} \mathrm{C}$.

Table 2 presents the results of temperature shift-up experiments in which the virus-infected cells were incubated at $25^{\circ} \mathrm{C}$ for 6 hours prior to

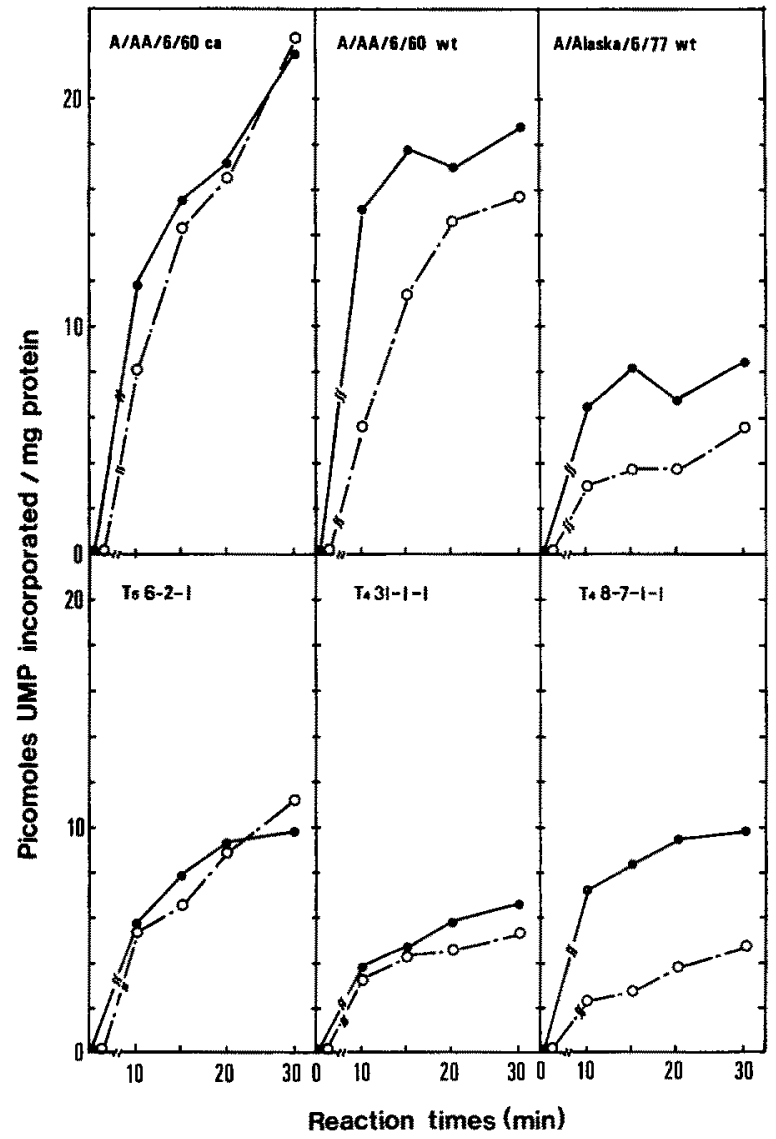

Fig. 1. Comparison of in vitro virion RNA polymerase activity at $25^{\circ} \mathrm{C}(0---0)$ and $33^{\circ} \mathrm{C}(\bullet-\bullet)$ 
incubation at $33^{\circ} \mathrm{C}$. Viral production by the ca variant occurred 3 hours earlier than that of $\mathrm{A} / \mathrm{AA} / 6 / 60 \mathrm{wt}$ strain. The yield of the wt strain lagged behind until 12 hours after infection. Clone $\mathrm{T}_{2}$ 36-3-1, which expresses ca phenotype and bears only the $\mathrm{PB} 2$ gene from $\mathrm{A} / \mathrm{AA} / 6 / 60$ ea variant with all remaining genes from wt A/Alaska/6/77 (Table 3), showed a viral growth pattern similar to that of the ca variant virus.

These experiments at latered temperatures seem to suggest that the ca mutation of $\mathrm{A} / \mathrm{AA} / 6 / 60$ ca variant affects the early rather than late stage of viral replication, resulting in a high virus yield at $25^{\circ} \mathrm{C}$.

\section{In vitro Virion RNA Polymerase Activity}

To determine whether the ca mutation of $\mathrm{A} / \mathrm{AA} / 6 / 60$ ca variant can be expressed as a phenotype with higher virion RNA polymerase activity at $25^{\circ} \mathrm{C}$, the polymerase activity was analyzed by the incorporation of ${ }^{3} \mathrm{H}$ uridine triphosphates ( $\left.{ }^{3} \mathrm{H}-\mathrm{UTP}\right)$. The kinetics of the enzyme activity of the ca reassortants and their parental viruses in 10 repeated determinations are shown in Fig. 1. Both A/AA/6/60 ca variant and A/AA/6/60 wt strains exhibited higher polymerase activity at $33^{\circ} \mathrm{C}$, however, the enzyme activity of A/Alaska/6/77 virus was considerably lower (upper panels). The maximum activities (picomoles UMP incorporated $/ \mathrm{mg}$ protein) of these viruses were $22.00,18.86$ and 8.40 , respectively. Low enzyme activity at $33^{\circ} \mathrm{C}$ was also observed in the ca reassortants (lower panels). These ca reassortants possess a majority of gene segments originating from A/Alaska/6/77 strain (Table 3).

Table 3. Gene constellations and biological properties of ca reassortant viruses ${ }^{\text {a }}$

\begin{tabular}{|c|c|c|c|c|c|c|c|c|c|}
\hline \multirow[b]{2}{*}{ Viruses } & \multirow[b]{2}{*}{ Phenotypes } & \multicolumn{8}{|c|}{ RNA segments } \\
\hline & & $\begin{array}{l}1 \\
(\mathrm{PA})\end{array}$ & $\begin{array}{l}2 \\
\text { (PB 2) }\end{array}$ & $\begin{array}{l}3 \\
\text { (PB 1) }\end{array}$ & $\begin{array}{l}4 \\
(\mathrm{HA})\end{array}$ & $\begin{array}{l}5 \\
(\mathrm{NA})\end{array}$ & $\begin{array}{l}6 \\
(\mathrm{NP})\end{array}$ & $\begin{array}{l}7 \\
\text { (M) }\end{array}$ & $\begin{array}{l}8 \\
(\mathrm{NP})\end{array}$ \\
\hline $\mathrm{T}_{2} 36-3-1$ & ca and non ts & $w t^{b}$ & $\mathrm{AA}^{\mathrm{c}}$ & wt & $w t$ & wt & wt & wt & wt \\
\hline $\mathrm{T}_{4} 31-1-1$ & ca and non ts & $w \mathrm{t}$ & $\mathrm{AA}$ & wt & $\mathrm{wt}$ & wt & wt & wt & wt \\
\hline $\mathrm{T}_{4} 8-7-1-1$ & ea and non ts & wt & wt & wt & wt & $\mathrm{AA}$ & wt & wt & wt \\
\hline $\mathrm{T}_{6} 6-2-1$ & ca and ts & wt & AA & AA & wt & $\mathrm{AA}$ & wt & wt & wt \\
\hline
\end{tabular}

a Taken from ODAGIRI et al. (23)

b wt RNA derived from A/Alaska/6/77 (H 3 N 2) wild type virus

c AA RNA derived from A/Ann Arbor/6/60 (H 2N 2) ca variant virus

Presumably the basis for depressed enzyme activity resides in these shared genes. This low enzymic activity at $33^{\circ} \mathrm{C}$ might be attributed to the influence of matrix (M) protein of A/Alaska/6/77 strain as was previously shown for vesicular stomatitis virus (4) and also for influenza virus (33). Investigations are now in progress to explore this possibility. 
Comparing the polymerase activity between $25^{\circ}$ and $33^{\circ} \mathrm{C}$ in each strain, $\mathrm{A} / \mathrm{AA} / 6 / 60$ ca variant and the ca reassortants which possessed the PB2 gene of the ca variant ( $T_{6} 6-2-1$ and $T_{4}$ 31-1-1) exhibited similar patterns of enzyme activity at $25^{\circ}$ and $33^{\circ} \mathrm{C}$. This was in contrast to the polymerase activities of two wt virus and a ca reassortant, containing three polymerase genes from A/Alaska/6/77 (T 4 8-7-1-1), which were markedly low at $25^{\circ} \mathrm{C}$. These results clearly indicate that the ca mutation residing on the PB2 gene of the ca variant can be expressed as a phenotype of high polymerase activity at $25^{\circ}$ as well as at $33^{\circ} \mathrm{C}$.

\section{Synthesis of Viral cRNA in the Primary Transcription}

For measurement of viral cRNA products synthesized in the primary transcription, cRNA extracted from virus-infected cells, which were treated with cycloheximide (CM) from the beginning of infection, was annealed with ${ }^{3} \mathrm{H}$-labeled virion RNA ( $\left.{ }^{3} \mathrm{H}-\mathrm{vRNA}\right)$. In preliminary experiments (data not shown), the rate of appearance of cRNA of $A / A A / 6 / 60$ ca variant after infection reached a maximum between 4 and 6 hours at $25^{\circ} \mathrm{C}$ and between 2 and 4 hours at $33^{\circ} \mathrm{C}$. The transcripts gradually decreased with further incubation. These findings correlated with the results of maximum ${ }^{3} \mathrm{H}$ uridine incorporation into the infected cells at, 5 hours $\left(25^{\circ} \mathrm{C}\right)$ and 3 hours $\left(33^{\circ} \mathrm{C}\right)$ in the presence of CM (data not shown).

Table 4. Hybridization analysis of viral cRNA synthesized in the presence of cycloheximide

\begin{tabular}{lllccc}
\hline & \multicolumn{2}{c}{ eRNA synthesized $(\mu \mathrm{g})^{\mathrm{a}}$} & & \multicolumn{2}{c}{$\begin{array}{c}\text { Ratio of eRNA synthesized } \\
\text { to } \mathrm{A} / \mathrm{AA} / 6 / 60 \text { ca variant }\end{array}$} \\
\cline { 2 - 3 } \cline { 5 - 6 } Viruses & at $25^{\circ} \mathrm{C}$ & at $33^{\circ} \mathrm{C}$ & & at $25^{\circ} \mathrm{C}(\%)$ & at $33^{\circ} \mathrm{C}(\%)$ \\
\hline $\mathrm{A} / \mathrm{AA} / 6 / 60 \mathrm{ca}$ & 0.225 & 0.236 & & 100 & 100 \\
$\mathrm{~A} / \mathrm{AA} / 6 / 60 \mathrm{wt}$ & 0.052 & 0.174 & & 23.1 & 73.7 \\
$\mathrm{~T}_{2} 36-3-1 \mathrm{ca}$ & 0.195 & 0.167 & & 86.7 & 70.8 \\
\hline
\end{tabular}

a Cytoplasmie RNA was extracted and annealed to $3 \mu \mathrm{g}$ of ${ }^{3} \mathrm{H}$-uridine labeled viral RNA $(18,000 \mathrm{cpm} / \mu \mathrm{g}$ RNA to $48,500 \mathrm{cpm} / \mu \mathrm{g}$ RNA). The amount of viral RNA rendered RNase resistant after annealing represents the amount of viral cRNA synthesized in the infected cells

The maximum amount of $\mathrm{eRNA}$ synthesized by the ea and the wt viruses at $25^{\circ}$ and $33^{\circ} \mathrm{C}$ is shown in Table 4 . The production of $\mathrm{eRNA}$ by $\mathrm{A} / \mathrm{AA} / 6 / 60$ ca variant was nearly equal at $25^{\circ}$ and $33^{\circ} \mathrm{C}$. The $\mathrm{PB} 2$-single gene ca reassortant $T_{2}$ 36-3-1 also exhibited similar properties, although its maximum products were approximately 15 to 30 per cent less at each temperature than the ca variant strain. In contrast, the cRNA products of $\mathrm{A} / \mathrm{AA} / 6 / 60 \mathrm{wt}$ was significantly lower at $25^{\circ} \mathrm{C}$ than its products at $33^{\circ} \mathrm{C}$. As a result, the amount of cRNA synthesized at $25^{\circ} \mathrm{C}$ was a quarter of the amount synthe- 
sized by the ca variant at the same temperature. These results indicate that the PB2-ca mutation enhances viral primary transeription at low temperature.

Previously, HaY et al. (10) reported that no detectable synthesis of unpolyadenylated cRNA, which functions as a template for $\mathrm{vRNA}$ synthesis,

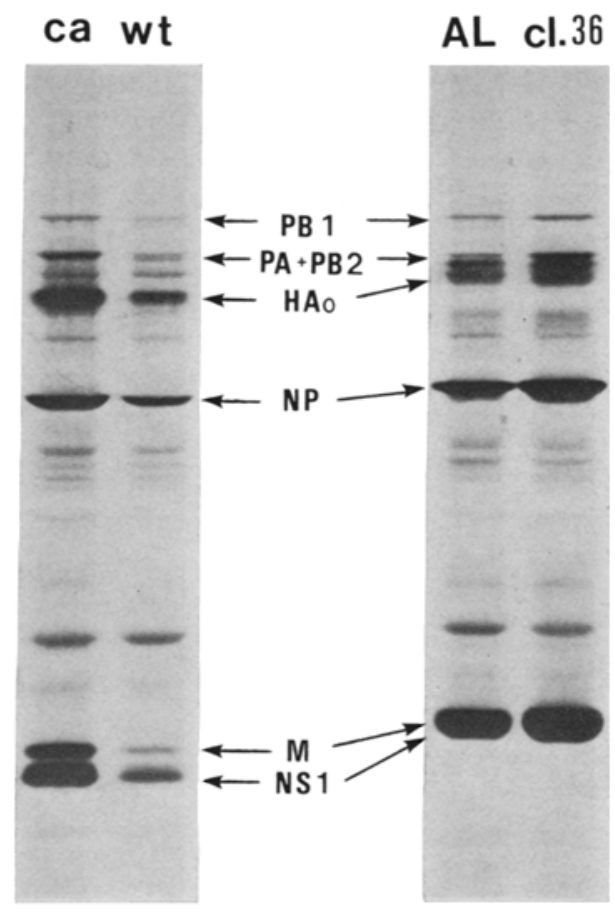

Fig. 2. Viral polypeptides translated from viral cRNA synthesized at $25^{\circ} \mathrm{C}$ in the presenee of cycloheximide (CM). MDCK cells were infected at an MOI of $50 \mathrm{PFU} / \mathrm{cell}$ in the presence of $100 \mu \mathrm{g} / \mathrm{ml} \mathrm{CM}$ and incubated for 3 hours at $25^{\circ} \mathrm{C}$ in the presence of CM. The cells were then treated with $2 \mu \mathrm{g} / \mathrm{mI}$ actinomycin $\mathrm{D}$ for 1 hour at $25^{\circ} \mathrm{C}$. After removal of the drugs, the cells were incubated for 4 hours at $33^{\circ} \mathrm{C}$ and labeled with $30 \mu \mathrm{Ci} / \mathrm{ml}{ }^{14} \mathrm{C}$-L-amino acid mixtures for 20 minutes, as described in Materials and Methods. The samples were subjected to electrophoresis on a 10 per cent gel and fluorographed for 7 days at $-80^{\circ} \mathrm{C}$. ca A/AA/6/60 ca variant; wt A/AA/6/60 wt strain; $A L$ A/Alaska/6/77 wt strain; cl. $36 \mathrm{~T}_{2} 36-3-1$ ea reassortant

oceurred in infected cells treated with $\mathrm{CM}$ from the beginning of infection. Thus, the cRNA measured in this primary transcription experiments represented messenger RNA (mRNA). To demonstrate whether the transcripts synthesized under our experimental conditions function as mRNA in infected cells, we undertook primary translation experiments. Infected. cells were incubated at $25^{\circ} \mathrm{C}$ for 3 hours in the presence of CM and the cells were subsequently treated with actinomycin $\mathrm{D}$ for 1 hour at $25^{\circ} \mathrm{C}$ to block further cRNA synthesis (26). The transcripts synthesized under limited 
conditions by actinomycin $\mathrm{D}$ were translated in the cells after removal of the drugs at $33^{\circ} \mathrm{C}$ for 4 hours as shown in Fig. 2. The temperature of $33^{\circ} \mathrm{C}$ was chosen to avoid any differences in the translation rate between the ca mutants and the wt viruses. The relative amount of the ca variant and the PB2 single-gene reassortant translates were greater than those of the wt viruses.

The finding suggests that the primary trangeripts affected by the PB2ca mutation were mainly, if not all, miNA.

\section{Synthesis of Viral Polypeptides at $25^{\circ} \mathrm{C}$}

Viral polypeptides synthesis in the virus-infected cells at $25^{\circ} \mathrm{C}$ was characterized at various times past-infection (p.i.). Polypeptide synthesis

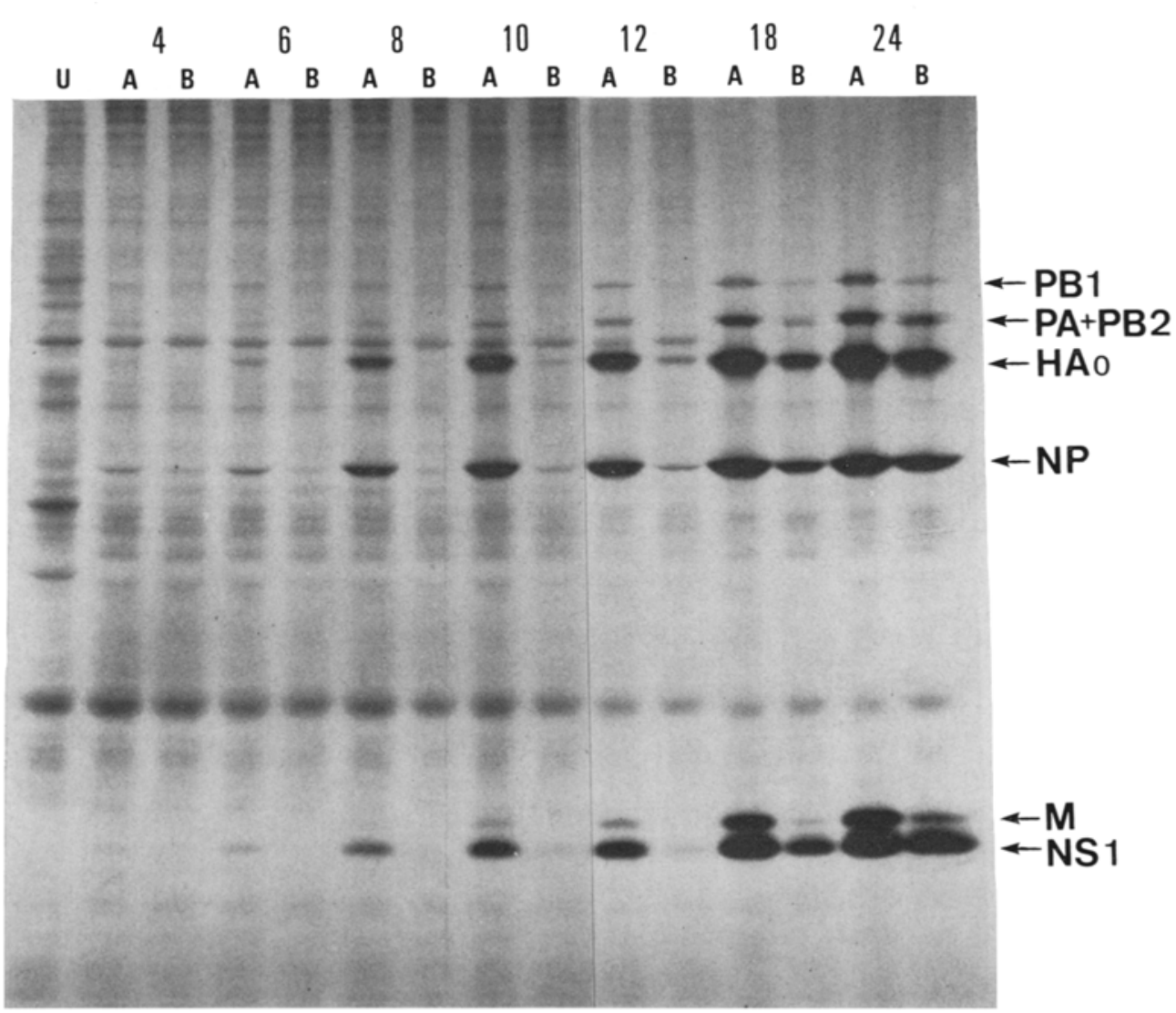

Fig. 3. Synthesis of viral polypeptides at $25^{\circ} \mathrm{C}$ in virus-infected MDCK cells. The infected cells were incubated at $25^{\circ} \mathrm{C}$ for the hours indicated at the top of each column. The samples labeled, as described in Materials and Methods, were subjected to electrophoresis on a 10 per cent gel and fluorographed for 14 days at $-80^{\circ} \mathrm{C}$. $U$ uninfected cell; $A A / \mathrm{AA} / 6 / 60$ ca variant; $B A / A \mathrm{~A} / 6 / 60$ wt strain. 
at $33^{\circ} \mathrm{C}$ which corresponds to normal infection was also examined. At this temperature the polypeptides of both ca variant and the wt viruses were detected at 2 hours p.i., with no significant differences in the amount of products observed (data not shown). However, at $25^{\circ} \mathrm{C}$ the time required for the appearance of each viral polypeptide was markedly different as can be seen in Fig. 3. The nucleoprotein (NP) and nonstructural proteins (NS) of the ca variant were detected at 6 hours p.i. (lane $6 \mathrm{~A}$ ). These polypeptides were gradually accumulated under subsequent incubation at $25^{\circ} \mathrm{C}$. The M protein of the ca variant was detected at 10 hours p.i. (lane 10 A) and all of the polypeptides attained their maximum levels by 18 hours p.i. (lane $18 \mathrm{~A})$. On the contrary, no visible viral polypeptide synthesis of the wt strain was observed until 10 hours p.i. (lanes $4 \mathrm{~B}$ to $10 \mathrm{~B}$ ), with synthesis becoming significant from 12 hours p.i. (lane 12B).

Rough quantitative comparison of the polypeptide products of these two viruses was also performed by densitometer tracing. The total amount of wt viral polypeptide synthesized at 24 hours p.i. was calculated to be approximately 56 per cent of the polypeptide synthesized by the ca variant. In addition, the polypeptide synthesis of the wt virus at 24 hours p.i. corresponded to that of the ea variant at 18 hours p.i. (compare lanes $18 \mathrm{~A}$ and $24 \mathrm{~B})$.

\section{Discussion}

A ca mutation contributing to the ca property of $\mathrm{A} / \mathrm{AA} / 6 / 60$ variant strain was identified as residing on the $\mathrm{PB} 2$ gene of the variant strain by the following findings; i) some ca mutants which expressed only ca phenotype were "PB2 single-gene" reassortant viruses (23) and ii) electrophoretic analysis of viral polypeptides in infected cells at $33^{\circ} \mathrm{C}$ showed that only the PB2 protein of $\mathrm{A} / \mathrm{AA} / 6 / 60$ variant migrated more slowly than that of the wt strain (unpublished data). The present study is the first attempt to delineate the function of the ca mutation(s) residing on the PB2 gene (PB2-ca mutation) of the ca variant strain using the PB2 single-gene reassortant virus.

The comparative analysis of viral growth curves from temperature shift experiments indicated that $\mathrm{A} / \mathrm{AA} / 6 / 60$ ca variant grew equally well at $25^{\circ}$ and $33^{\circ} \mathrm{C}$ regardless of any shifts in the incubation temperature. This was not true with the wt virus whose growth was markedly delayed and whose yield was depressed when the wt virus-infected cells were placed at the low temperature during the early stage of the viral replication. This phenomenon correlated with the finding that at $25^{\circ} \mathrm{C}$ synthesis of the wt polypeptides occurred 6 hours later than synthesis of the ca variant polypeptides and that the maximum polypeptide production was only half of the ca variant product. The fact that the ca virus' growth range is expanded to $25^{\circ} \mathrm{C}$ 
strongly suggests that at least one of the ca mutations of the ca variant strains plays an important role in the early stage of viral replication.

The optimal temperature for in vitro enzyme activity of virion RNA polymerase is reported to be between $31^{\circ}$ and $33^{\circ} \mathrm{C}(2)$. At $25^{\circ} \mathrm{C}$ the activities of any influenza wt strains do not surpass their activities at the optimal temperature $(11,22)$. The ca $\mathrm{A} / \mathrm{AA} / 6 / 60$ variant and any ca reassortants containing the $\mathrm{A} / \mathrm{AA} / 6 / 60 \mathrm{~PB} 2$ gene, however, exhibited identical activities at both $25^{\circ}$ and $33^{\circ} \mathrm{C}$ in our assay. The low polymerase activity of A/Alaska/ $6 / 77 \mathrm{wt}$ strain at $25^{\circ} \mathrm{C}$ increases until it reaches a level similar to that at $33^{\circ} \mathrm{C}$ if the PB2 gene of A/Alaska/6/77 is exchanged for the PB2 gene of the ca variant by genetic reassortment, as can be seen for $\mathbf{T}_{4}$ 31-1-1. From the in vitro polymerase assays, it was apparent that the $\mathrm{PB} 2$ gene of $\mathrm{A} / \mathrm{AA} /$ $6 / 60$ ca variant strain can affect the phenotype of enzyme activity at $25^{\circ} \mathrm{C}$. In addition, $\mathrm{A} / \mathrm{AA} / 6 / 60$ ca variant's polymerase in the temperature-sensitive property was considerably more heat labile than the wt polymerase when treated for 10 minutes at $39^{\circ} \mathrm{C}$ and this thermal lability is attributed to the PB 2 protein of the ca variant strain (in preparation).

Because the ca variant and the reassortants containing only the PB2 gene from $\mathrm{A} / \mathrm{AA} / 6 / 60$ synthesized polypeptides in twice the abundance of the wt virus' in infected cells at $25^{\circ} \mathrm{C}$, we were led to predict that at $25^{\circ} \mathrm{C}$ the virus strains containing the $\mathrm{PB} 2$-ca mutation would synthesize a greater amount of mRNA than the wt strain. Both unpolyadenylated eRNA and vRNA are not detected in the presence of cycloheximide (CM) $(1,20)$. Therefore, quantitative analysis of viral cRNA synthesized in the presence of $\mathrm{CM}$ in our experiments demonstrated that the ca variant $(\mathrm{A} / \mathrm{AA} / 6 / 60)$ produced equal amount of eRNA at $25^{\circ}$ and $33^{\circ} \mathrm{C}$ and that this amount was approximately four-fold greater than the wt cRNA synthesized at $25^{\circ} \mathrm{C}$. The PB2 single-gene reassortant virus acted in a similar manner. Thus the evidence strongly suggests that the PB2-ca mutation was expressed at the first step in viral mRNA synthesis at $25^{\circ} \mathrm{C}$. When viral mRNA is synthesized, the PB 2 protein functions in recognition and binding of the cap 1 structure as a primer during the endonuclease reaction $(3,30,31)$.

Using the methods of T1 oligonucleotide mapping and RNA-RNA hybridization, Cox et al. (7) showed that $\mathrm{A} / \mathrm{AA} / 6 / 60$ ca variant strain possesses mutations in all eight gene segments. It is not clear whether the ca mutation on the PB1 gene segment of the ca variant affects the initiation and elongation step in viral mRNA synthesis caused by PB 1 protein (3). Furthermore the ca mutation on the A/AA/6/60 variant neuraminidase (NA) gene that presumably functions in the late stage of the viral replication remains to be determined. However, the assessment of the ca mutations using the single-gene reassortants of $\mathrm{A} / \mathrm{AA} / 6 / 60$ variant strain as shown in the present study can be a useful approach in clarifying the mechanism of viral replication at low temperature. 


\section{Acknowledgments}

We thank Drs. K. Shimizu and D. C. DeBorde, and Mr. A. Donabedian for their in valuable discussions. This work was supported by Grants in aid for Scientific Research from the Ministry of Education, Science and Culture, and from the Ministry of Public Health and Welfare of Japan. H.F.M. was supported by Contract No. 1-AI72521, National Institute of Allergy and Infectious Diseases, Development and Applications Branch, Bethesda, Maryland 20205, U.S.A.

\section{Reierences}

1. Barrett, T., Wolstenholme, A. J., Mahy, B. W.: Transeription and replication of influenza virus RNA. Virology 98, 211-225 (1979).

2. Bishop, D. H. L., OвIJеskI, J. F., Snupson, R. W.: Transcription of the influenza ribonucleic acid genome by a virion polymerase. I. Optimal conditions for in vitro activity of the ribonucleic acid dependent ribonucleic acid polymerase. J. Virol. 8, $66-73(1971)$.

3. Braam, J., Ulmanen, I., Krug, R. M.: Molecular model of a eucaryotic transcription complex : Functions and movements of influenza $P$ proteins during capped RNA-primed transcription. Cell. 34, $609-618$ (1983).

4. Carrol, A. R., Wagner, R. R.: Role of the membrane (M) protein in endogenous inhibition of in vitro transeription. by vesicular stomatitis virus. J. Virol. 29, $134-142(1979)$.

5. Clements, M. L., O’Donnell, S., Levjne, M. M., Chanock, R. M., Murphy, B. R.: Dose response of $\mathrm{A} /$ Alaska/6/77 ( $\mathrm{H} 3 \mathrm{~N} 2$ ) cold-adapted reassortant vaccine virus in adalt volunteers: Role of local antibody in resistance to infection with vaccine virus. Infect. Immun. 40, 1044-1051 (1983).

6. Cox, N. J., MaAssab, H. F., Kendal, A. P.: Comparative studies of wild-type and cold-mutant (temperature sensitive) influenza viruses: Nonrandon reassortment of genes during preparation of live virus vaccine candidates by recombination at $25^{\circ} \mathrm{C}$ between recent $\mathrm{H} 3 \mathrm{~N} 2$ and $\mathrm{H} 1 \mathrm{~N} 1$ epidemic strains and cold-adapted $\mathrm{A} / \mathrm{Ann}$ Arbor/6/60. Virology 97, 190-194 (1979).

7. Cox, N. J., Konneck, I., Kendad, A. P., Maassar, H. F.: Genetic and biochemical analysis of the A/Ann Arbor/6/60 cold-adapted mutant. In: NAYAK, D. (ed.), Genetic Variation among Influenza Viruses, 639-652. New York: Academic Press 1981.

8. Cox, N. J., Kendal, A. P.: Genetic stability of A/Ann Arbor $/ 6 / 60$ cold-mutant (temperature-sensitive) live influenza virus genes: Analysis by oligonucleotido mapping of recombinant vaccine strains before and after replication in volunteers. J. Infect. Dis. 149, 194-200 (1984).

9. Glass, S. E., MoGEOCH, D., BARRY, R. D.: Characterization of the mRNA of influenza virus. $J$. Virol. 16, 1435-1443(1975).

10. Hay, A. J., Lomniczi, B., Bertamy, A. R., Skehei, J. J.: Transeription of the influenza virus genome. Virology $83,337-355$ (1977).

11. Kmandi, A. P., Cox, N. J., Galphin, J. C., MaAssab, H. F.: Comparative studies of wild-type and cold-mutant (temperature-sensitive) influenza viruses: Independent segregation of temperature-sensitivity of virus replication from temperature-sensitivity of virion transeriptase activity during recombination of mutant A/Ann Arbor/6/60 with wild-type H $3 \mathrm{~N}_{2}$ strains. J. gen. Virol. 44, 443-456 (1979).

12. KrUa, R. M., Ueda, M., Parese, P.: Temperature-sensitive mutants of influenza WSN virus defective in virus-specific RNA synthesis. J. Virol. 16, 790-796 (1975). 
13. Lammmir, U. K.: Cleavage of structural protein during the assembly of the heat of bacteriophage T 4. Nature (London) 227, 680-685 (1970).

14. LAmcs, A. R., Choppin, P. W.: Synthesis of influenza virus proteins in infected cells: Translation of viral polypeptides, including three $\mathrm{P}$ polypeptides from RNA produced by primary transcription. Virology 74, 504-519 (1976).

15. Lamr, R. A., Emind, P. R., Choppin, P. W.: Evidence for a ninth influenza viral polypeptide. Virology 91, 60-78 (1978).

16. MAASSAB, H. F.: Adaption and growth characteristics of influenza virus at $25^{\circ} \mathrm{C}$. Nature (London) 213, 612-614 (1967).

17. MAASSAB, H. F. : Biologic and immunologic characteristics of cold-adapted influenza virus. J. Immunol. 102, 728-732 (1969).

18. MAASSAB, H. F.: Development of variants of influenza virus. In: BARRY, R. D., MAHY, B. W. J. (eds.), The Biology of Large RNA Viruses, 542-566. New York: Academic Press 1970.

19. MAassab, H. F., DeBorde, D. C.: Characterization of influenza A host range mutant. Virology 130, 342-350 (1983).

20. MARK, G. E., TAYLOR, J. M., BRon, B., KRUG, R. M. : Nuclear accumulation of influenza viral RNA transcripts and the effects of cycloheximide, actinomycin D, and $\alpha$-amamitin. J. Virol. 29, 744-752 (1979).

21. Morttz, A. J., Kunz, C., Hofman, H., LieHt, E., Reev, P., Maassab, H. F.: Studies with a cold-recombinant A/Victoria/3/75 (H 3 N 2) virus. II. Evaluation in adult volunteers. J. Infect. Dis. 142, $857-860$ (1980).

22. Mowsmowry, S. L., UEDA, M.: Temperature-sensitive virion transcriptase aetivity in mutants of WSN influenza virus. Arch. Virol. 52, 135-141 (1976).

23. Odagmi, T., DeBonde, C. D., Maassab, H. F.: Cold-adapted recombinants of influenza $A$ virus in MDCK cells. I. Development and characterization of A/Ann Arbor $/ 6 / 60 \times \mathrm{A} /$ Alaska/6/77 recombinant viruses. Virology 119, 82 - 95 (1982).

24. Odagiri, T., Smmka, C. W., MaAssab, H. F. : Cold-adapted reassortants of influenza A virus in MDCK cells. II. Role of the temperature-sensitive property of coldadapted in mice. Microbiol. Immunol. 27, 203-206 (1983).

25. Pцотсн, S. J., KRUG, R. M.: Influenza virion transcriptase: Synthesis an vitro of large, polyadenylic acid-containing complementary RNA. J. Virol. 21, 24-34 (1977).

26. Pons, M. W.: Early RNA synthesis in influenza virus-infected cells. Virology 76, $855-859(1977)$.

27. Sprtng, S. B., Maassab, H. F., Kendat, A. P., Murphy, B. R., Chanook, R. M.: Cold-adapted variants of influenza A. II. Comparison of the genetie and biologieal properties of ts mutations and recombinants of the cold-adapted A/AA/6/60 strain. Arch. Virol. 55, 233-246 (1977).

28. Sugiura, A., Ueda, M., Тobita, K., Enomoto, C.: Further isolation and characterization of temperature-sensitive mutations of influenza virus. Virology 65 , $363-373(1975)$.

29. Tannock, G. A., Paut, J. A., Barry, R. D.: Relative immunogenicity of the cold-adapted influenza virus A/Ann Arbor/6/60 (A/AA/6/60) recombinants of $\mathrm{A} / \mathrm{AA} / 6 / 60-\mathrm{ca}$, and parental strains with similar surface antigens. Infect. Immun. 43, $457-462(1984)$.

30. Ulmanen, I., Bront, B. A., Krug, R. M.: Role of two of the influenza virus core $P$ proteins in recognizing cap 1 structures $\left(\mathrm{m}^{7} \mathrm{GpppNm}\right)$ on RNAs and in initiating viral RNA transcription. Proc. Natl. Acad. Sci. U.S.A. 78, 7355 - 7359 (1981).

31. Ulmanen, I., Broni, B., KRUG, R. M. : Influenza virus temperature-sensitive cap $\left(m^{7} G\right.$ pppNm)-dependent endonuclease. J. Virol. 45, 27-35 (1983). 
104 T. Odagiri, A.Tosaka, N. Ishrdd, and H. F. MAAssab : Influenza AVirusca Mutation

32. Yamane, N., Nakamura, Y., Yuki, M., Odagiri, T., Ishida, N.: Serological evaluation of an influenza $A$ virus cold-adapted reassortant live vaccine, CR-37 (H 1 N 1), in Japanese adult volunteers. J. Hyg. (Camb.) 92, 231-242 (1984).

33. Zvonarjey, A. Y., GHendon, Y. Z.: Influence of membrane (M) protein on influenza A virus virion transeriptase activity in vitro and its susceptibility to rimantadine. J. Virol. 33, 583-586 (1980).

Authors' address: Dr. T. Odagiri, Department of Virology, Jichi Medical School, Minamikawachi-machi, Kawachi-gun, Tochigi-ken, 329-04 Japan.

Received March 8, 1985 